\title{
ANALISIS RASIO LIKUIDITAS DAN PROFITABILITAS SEBAGAI ALAT EVALUASI KINERJA KEUANGAN KOPERASI KARYAWAN PT. PUSRI PALEMBANG
}

\author{
Oleh: Fatimah Adlia \\ (SMK MUHAMMADIYAH 3 PALEMBANG)
}

fatimahadlia65@gmail.com

\begin{abstract}
Abstrak-Tujuan dari penelitian ini untuk mengetahui rasio likuiditas dan profitabilitas pada Koperasi Karyawan PT. Pusri Palembang. Metode penelitian yang digunakan analisis deskriptif kuantitatif. Teknik pengumpulan data yang digunakan teknik dokumentasi, observasi dan wawancara. Hasil penelitian menunjukkan rasio likuiditas koperasi; dilihat dari aspek current ratio, quick ratio, rasio kas atas aktiva lancar, rasio kas atas utang lancar, rasio aktiva lancar dan total aktiva dan rasio aktiva lancar dan total utang pada tahun 2015 sampai 2017 berada pada kategori cukup sehat. Sedangkan Rasio Profitablitas/rentabilitas dilihat dari aspek net profit margin, gross profit margin, return on asset, dan return on equity pada tahun 2015 sampai 2017 berada pada kategori sangat sehat karena mengalami peningkatan yang cukup signifikan disetiap tahunnya.
\end{abstract}

Kata Kunci : Laporan Keuangan, Rasio Keuangan

Abstract-The purpose of this study was to determine the liquidity and profitability ratios of PT. Pusri Palembang. The research method used is quantitative descriptive analysis. Data collection techniques used were documentation, observation and interview techniques. The results showed a cooperative liquidity ratio; seen from the aspect of the current ratio, quick ratio, cash to current assets ratio, cash to current debt ratio, current asset ratio and total assets and current asset ratio and total debt in 2015 to 2017 are in the quite healthy category. While the Profitability / Profitability Ratio seen from the aspects of net profit margin, gross profit margin, return on assets, and return on equity in 2015 to 2017 is in the very healthy category because it has increased significantly every year.

Keywords: Financial Statements, Financial Ratios

PENDAHULUAN

Kegiatan ekonomi dalam struktur perekonomian Indonesia di bagi menjadi 3 (tiga) yaitu BUMN (Badan Usaha Milik Negara), BUMS (Badan Usaha Milik Swasta), dan Koperasi. Salah satu pilar ekonomi yang dianggap mampu untuk $\begin{array}{lr}\text { mewujudkan } & \text { kesejahteraan } \\ \text { masyarakat } & \text { Indonesia adalah } \\ \text { koperasi. } & \end{array}$

Koperasi merupakan lembaga yang menjalankan suatu kegiatan usaha dan pelayanan yang dimaksud dapat berupa pelayanan kebutuhan keuangan, pengkreditan, kegiatan 
pemasaran, atau kegiatan-kegiatan lain. Selain itu, koperasi adalah badan usaha yang beranggotakan orang-seorang atau badan hukum koperasi, dengan pemisahan kekayaan para anggotanya sebagai modal untuk menjalankan usaha yang memenuhi aspirasi dan kebutuhan bersama dibidang ekonomi, sosial, dan budaya sesuai dengan nilai dan prinsip-prinsip koperasi (Undang-Undang Republik Indonesia No. 17 tahun 2012 tentang Perkoperasian).

Dalam koperasi memiliki prinsip keanggotaan bersifat sukarela dan terbuka, pengelolaan dilaksanakan secara demokratis, pembagian SHU (Sisa Hasil Usaha) dilakukan secara adil dan sebanding dengan besarnya jasa usaha masingmasing anggota, pemberian balas jasa yang terbatas terhadap modal, serta kemandirian. Prinsip tersebut menjadi keunggulan koperasi dibandingkan usaha lainnya, dan dari itu diharapkan mampu mewujudkan cita-cita bangsa Indonesia yang adil, sejahtera dan makmur.

Berhasil atau tidaknya usaha koperasi tergantung bagaimana para anggota dan pengelola koperasi dapat bekerja seefektif dan seefisien mungkin pada segi peningkatan kinerja keuangan koperasi. Keberhasilan dalam mencapai tujuan tersebut merupakan prestasi bagi pihak pengelola koperasi. Penilaian kinerja keuangan suatu koperasi dapat diukur karena sebagai bahan evaluasi dalam pengambilan keputusan atau kebijakan-kebijakan yang akan digunakan untuk tahun atau periode-periode yang akan datang. Kinerja keuangan koperasi ini dapat diukur dengan menggunakan analisis laporan keuangan.

Analisis laporan keuangan adalah suatu proses untuk menelaah masing-masing unsur laporan keuangan yang merupakan proses yang penuh pertimbangan sehingga dapat dihasilkan suatu prediksi, gambaran yang akurat untuk masa yang akan datang. Dalam menganalisis laporan keuangan diperlukan data keuangan yang telah ada dan akan dipakai sebagai dasar pengukuran. Pada umumnya ada beberapa analisis laporan keuangan yang sering kali digunakan yaitu analisis rasio likuiditas, analisis rasio solvabilitas, analisis rasio profitabilitas, dan analisis rasio aktivitas. Hasil pengukuran tersebut biasanya digunakan untuk mengetahui sejauhmana keberhasilan koperasi mencapai target yang telah ditentukan dalam satu periode berjalan.

Koperasi memiliki peran yang sangat besar dalam perkembangan perekonomian di Indonesia dewasa ini banyak bermuculan koperasikoperasi yang mempunyai unit kegiatan usaha yang tidak sedikit. Salah satunya Koperasi Karyawan PT. Pusri Palembang. 
Koperasi Karyawan PT. Pusri Palembang merupakan koperasi yang didirikan di lingkungan perusahaan yang berlokasi di Jl. Melur No.8 Komplek PT. Pusri Palembang yang telah mempunyai badan hukum dengan nomor 002105/BH/XX tanggal 28 agustus 1980. Anggota dari koperasi ini terbatas hanya untuk karyawan dan pesiunan PT. Pusri Palembang. Koperasi ini dibuka setiap hari senin sampai jumat dari jam 07.30 sd 16.30 WIB. Sifat dari koperasi karyawan ini juga sangat terbuka dan sukarela, tidak ada paksaan bagi para karyawan untuk harus mengikuti menjadi anggota koperasi karyawan. Selain itu, terbuka disini maksudnya setiap orang atau masyarakat umum boleh membeli barang dan jasa yang telah disediakan di koperasi karyawan ini.

Koperasi Karyawan PT.Pusri Palembang mempunyai dua jenis koperasi yaitu koperasi simpan pinjam dan koperasi konsumen. Koperasi simpan pinjam menyediakan dana atau pinjaman untuk para anggotanya yang relatif mudah dan cepat dengan simpanan pokok anggota sebesar Rp. 500.000 , simpanan wajib anggota sebesar Rp. 50.000 yang dipotong melalui slip gaji setiap bulan. Dan simpanan sukarela anggota. Sedangkan koperasi konsumen merupakan kegiatan usaha yang bersifat menghasilkan atau menyediakan barang dan jasa kebutuhan anggota koperasi dan non anggota koperasi, unit usahanya antara lain seperti usaha simpan pinjam, usaha air minum, usaha fotocopy, usaha service AC, usaha sewa kendaraan, usaha toko, usaha checker pupuk, usaha cleaning service, usaha handling, rebagging dan stacking, dan usaha pengadaan tenaga kerja.

Oleh karena itu, koperasi karyawan sangat perlu dan penting untuk dikelola dengan baik karena selain untuk meningkatkan kesejahteraan anggotanya dan masyarakat yang bukan anggota koperasi, ini juga mampu membuka lapangan pekerjaan bagi masyarakat baik yang berada dalam lingkungan perusahaan (yang bekerja di perusahaan) maupun diluar perusahaan (pabrik).

Dari hasil penelitian Aprilia (2012) yang berjudul Analisis Rasio keuangan Untuk Mengukur Kinerja Keuangan Pada Koperasi Dhaya Harta Jombang berdasarkan standar peraturan Menteri Negara Koperasi dan UKM Republik Indonesia diperoleh kesimpulan rasio likuiditas koperasi tergolong sangat sehat, rasio solvabilitas tergolong sehat, sedangkan rasio aktivitas dalam kondisi yang kurang sehat dan rasio profitabilitas tergolong tidak sehat.2 Berdasarkan hasil penelitian tersebut peneliti menyimpulkan bahwa pihak pengelola koperasi kurang efektif dan efesien dalam mengelola sumber aktiva yang ada. Hal itu terlihat dari profit yang dihasilkan koperasi belum maksimal dalam 
menghasilkan SHU koperasi sesuai dengan Standar Peraturan Menteri Koperasi dan Usaha Kecil Menengah Republik Indonesia Nomor : 06/Per/M.KUKM/V/2006.

Ketidakmampuan perusahaan (koperasi) membayar kewajibankewajibannya terutama utang jangka pendek (yang sudah jatuh tempo) disebabkan berbagai faktor, tidak jarang pula koperasi mengalami hal sebaliknya yaitu kelebihan dana. Artinya jumlah dana tunai dan dana yang segera dapat dicairkan melimpah.

Kejadian ini juga bagi koperasi kurang baik karena ada aktivitas yang tidak dilakukan secara optimal. Manajemen kurang mampu menjalankan kegiatan operasional, dalam hal menggunakan dana yang dimiliki. Sudah pasti hal ini akan mempengaruhi pencapaian laba yang diinginkan dan membuat laporan keuangan menjadi berfluktuasi setiap periode akuntansi.

Dengan demikian halnya pada Koperasi Karyawan PT. Pusri Palembang perlu diadakan analisis rasio laporan keuangan sebagai alat evaluasi kinerja keuangan koperasi. Menyimpulkan bahwa dengan menggunakan laporan keuangan maka akan diketahui sehat atau tidak sehatnya suatu kondisi keuangan pada koperasi tersebut yang dapat menggambarkan bagaimana prestasi kinerja keuangan dalam periode yang bersangkutan. Disamping itu juga dapat dijadikan alat dalam pertanggungjawaban pengurus koperasi pada rapat anggota tahunan.

Dari uraian di atas, maka penulis tertarik untuk mengadakan penelitian pada Koperasi Karyawan PT. Pusri Palembang dengan judul "Analisis Rasio Likuiditas dan Profitabilitas Sebagai Alat Evaluasi Kinerja Keuangan Koperasi PT.Pusri Palembang".

\section{METODE PENELITIAN}

Dalam penelitian ini peneliti menggunakan metode Analisis data deskriptif kuantitatif. Metode deskriptif adalah metode dalam meneliti status sekelompok manusia, suatu objek, suatu set kondisi, suatu sistem pemikiran, ataupun suatu kelas peristiwa pada masa sekarang. Tujuan dari penelitian deskriptif ini adalah untuk membuat deskripsi, gambaran atau lukisan secara sistematis, faktual, dan akurat mengenai fakta-fakta, sifat-sifat serta hubungan antarfenomena yang diselidiki. Sedangkan kuantitatif merupakan data yang berbentuk angka-angka yang bersumber dari data laporan keuangan koperasi karyawan PT. Pusri Palembang.

Pada penelitian ini mengacu pada Peraturan Menteri Negara Koperasi dan Usaha Kecil Menegah Republik Indonesia No.06/Per./M.KUKM/V/2006 tentang pedoman penilaian koperasi berprestasi/koperasi awards.

Adapun data yang digunakan adalah Laporan Keuangan Koperasi 
Karyawan PT. Pusri Palembang. Sumber data yang digunakan penulis dalam penelitian ini adalah:

\section{Data Primer}

Sumber data primer yaitu sumber data yang langsung memberikan data kepada pengumpul data (Moh Nazir, Me2014:43). Data primer pada penelitian ini dikumpulkan secara langsung dari objek yang teliti yaitu laporan keuangan Koperasi Karyawan PT. Pusri Palembang.

\section{Data Sekunder}

Data sekunder yaitu sumber yang tidak langsung memberikan data kepada pengumpul data (Sugiyono, 2016:137). Data sekunder diperoleh melalui dokumen-dokumen, laporan, dan bahan tertulis lainnya yang diperlukan yang ada di Koperasi Karyawan PT. Pusri Palembang.

\section{Teknik Pengumpulan Data}

Teknik pengumpulan data yang akan dilakukan yaitu :

\section{Dokumentasi}

Dokumentasi adalah mencari data mengenai hal-hal atau variabel yang berupa catatan, transkrip, surat kabar, majalah, prasasti, lengger, legenda, dan sebagainya (Suharsimi Arikunto, 2014:274). Dokumentasi digunakan untuk mengumpulkan data berupa laporan keuangan Koperasi Karyawan PT. Pusri Palembang tahun 2015 sampai dengan 2017.
2. Observasi

Observasi merupakan suatu proses yang kompleks, suatu proses yang tersusun dari berbagai proses biologis dan phisikologis, dua di antara yang terpenting adalah proses-proses pengamatan dan ingatan (Suharsimi Arikunto, 2014:137). Observasi dilakukan untuk mengetahui keadaan lingkungan perusahaan dan mengenal beberapa pimpinan dan karyawan yang berada di Koperasi Karyawan PT. Pusri Palembang.

3. Wawancara

Wawancara adalah proses memperoleh keterangan untuk tujuan penelitian dengan cara tanya jawab, smbil bertatap muka antara penanya dan narasumber atau responden dengan menggunakan alat yang dinamakan panduan wawancara (Moch.Nazir, 2014:170). Wawancara ini dilakukan dengan menggunakan wawancara terstruktur, karena peneliti telah meyiapkan beberapa pertanyaanpertanyaan yang diajukan kepada pihak responden.

\section{Teknik Keabsahan Data}

Teknik triangulasi diartikan sebagai teknik pengumpulan data yang bersifat menggabungkan dari berbagai teknik pengumpulan data dan sumber data yang telah ada. Menurut Sugiyono (2016:330) ada 
tiga macam teknik triangulasi sebagai berikut:

1. Triangulasi sumber

Triangulasi sumber untuk menguji kredialibilitas data dilakukan dengan cara mengecek data yang telah diperoleh melalui beberapa sumber.

\section{Triangulasi teknik}

Triangulasi teknik untuk menguji kredilibilitas data dilakukan dengan cara mengecek data kepada sumber yang sama dengan teknik yang berbeda.

\section{Triangulasi waktu}

Triangulasi waktu juga sering mempengaruhi kredibilitas data. Data yang dikumpul dengan teknik wawancara di pagi hari pada saat narasumber masih segar, belum banyak masalah akan memberikan data yang lebih valid sehingga lebih kredibel. Untuk pengujian kredibilitas dapat dilakukan dengan cara pengecekan dengan wawancara, observasi, atau teknik lain dalam waktu dan situasi yang berbeda.

\section{Teknik Analisis Data}

Analisis yang digunakan dalam penelitian ini adalah untuk mengetahui Analisis Rasio Likuiditas dan Profitabilitas Sebagai Alat Evaluasi Kinerja Keuangan Koperasi Karyawan PT. Pusri Palembang.

Tujuan utama rasio keuangan digunakan untuk menilai kemampuan perusahaan dalam memenuhi kewajibannya. Rasio likuiditas menggambarkan kemampuan perusahaan untuk menyelesaikan kewajiban jangka pendeknya. Rasio-rasio ini dapat dihitung melalui sumber informasi tentang modal kerja yaitu pos-pos aktiva lancar dan utang lancar.

1. Rasio likuiditas dapat dihitung dengan rumus:
a. Rasio Lancar (Current Ratio)
b. Rasio Cepat (Quick Ratio)
c. Rasio Kas atas Aktiva Lancar
d. Rasio Kas atas Utang Lancar
e. Rasio Aktiva Lancar dan Total Aktiva

f. Aktiva Lancar dan Total Utang Rasio Profitabilitas atau disebut juga rentabilitas menggambar kemampuan perusahaan mendapatkan laba melalui semua kemampuan, dan sumber yang ada seperti kegiatan penjualan, kas, modal, jumlah karyawan, dan sebagainya. Rasio ini menggambarkan kemampuan perusahaan menghasilkan laba disebut juga Operating Ratio.

2. Rasio Profitablitas dapat dihitung dengan rumus :

a. Margin Laba (Profit Margin)

b. Gross Profit Margin

c. Aset Turn Over (Return on Aset)

d. Return on Investment (Return on Equity)

e. Rentabilitas Modal Sendiri 
HASIL DAN PEMBAHASAN

\section{Hasil Penelitian}

1. Rasio Keuangan Koperasi

Karyawan PT. Pusri Palembang

terdiri dari :

1.1 Rasio Likuiditas

a. Current Ratio

Untuk mengukur likuiditas

Koperasi Karyawan PT. Pusri
Current ratio digunakan untuk membandingkan antara jumlah aktiva lancar dengan utang lancar. Adapun rumus dan hasil perhitungan Current Ratio pada Koperasi Karyawan PT. Pusri Palembang sebagai berikut :

$$
\mathrm{CR}=\frac{\text { Aktiva Lancar }}{\text { Utang Lancar }} \times 100 \%
$$

Palembang di gunakan current ratio.

Tabel 1. Perhitungan Current Ratio

\begin{tabular}{|r|r|r|l|}
\hline \multicolumn{1}{|c|}{ Tahun } & Aktiva Lancar & Utang Lancar & \% \\
\hline 2015 & Rp. 24.337 .188 .602 & Rp. 20.468 .206 .354 & $118,90 \%$ \\
\hline 2016 & Rp. 34.348 .947 .509 & Rp. 21.924 .336 .652 & $156,67 \%$ \\
\hline 2017 & Rp. 23.863 .314 .187 & Rp. 15.393 .222 .222 & $155,02 \%$ \\
\hline
\end{tabular}

Sumber: Laporan Keuangan Koperasi Karyawan PT. Pusri Palembang Data yang Telah Diolah.

Setelah besarnya rasio Palembang digunakan quick ratio. diketahui, selanjutnya dilakukan pengkatagorian terhadap rasio tersebut sesuai dengan Peraturan Menteri Koperasi Dan Unit Usaha Kecil Menengah Republik Indonesia Tahun 2006. Untuk pengkatagorian Current Ratiodi Koperasi Karyawan PT. Pusri Palembang dilihat dalam tabel berikut:

b. Rasio Cepat (Quick Ratio)

Untuk mengukur likuiditas Quick ratio ini menunjukkan besarnya alat likuid yang paling cepat yang bisa digunakan untuk melunasi utang lancar. dihitung dengan cara aktiva lancar dikurang persediaan ditambah biaya dibayar dimuka dibagi dengan utang lancar dikali dengan $100 \%$. Adapun rumus dan hasil perhitungan Quick Ratio pada Koperasi Karyawan PT. Pusri Palembang sebagai berikut :

Koperasi Karyawan PT. Pusri

$$
\mathrm{QR}=\frac{\text { Aktiva Lancar }-(\text { Persediaan }+ \text { Biaya Dibayar Dimuka })}{\text { Utang Lancar }} \times 100 \%
$$

Tabel 2. Perhitungan Quick Ratio

\begin{tabular}{|c|c|c|c|c|c|}
\hline Tahun & Aktiva Lancar & Persediaan & Biaya Dibayar Dimuka & Utang Lancar & \% \\
\hline 2015 & Rp.24.337.188.602 & Rp.962.564.123 & Rp.240.240.280 & Rp.20.468.206.354 & $113,02 \%$ \\
\hline 2016 & Rp.34.348.947.509 & Rp.910.731.397 & Rp.240.240.280 & Rp.21.924.336.652 & $151,42 \%$ \\
\hline 2017 & Rp.23.863.314.187 & Rp.691.075.269 & Rp.240.240.280 & Rp.15.393.222.122 & 148,97 \\
\hline
\end{tabular}

Sumber: Laporan Keuangan Koperasi Karyawan PT. Pusri Palembang Data yang Telah Diolah. 
c. Rasio Kas atas Aktiva Lancar

Untuk mengukur likuiditas Koperasi Karyawan PT. Pusri Palembang di gunakan rasio kas atas aktiva lancar. Rasio yang membandingkan antara kas dan aktiva lancar. Adapun rumus dan hasil perhitungan rasio kas atas aktiva lancarpada Koperasi Karyawan PT. Pusri Palembang sebagai berikut :

$$
\text { Rasio Kas atas Aktiva Lancar }=\frac{\text { Kas }}{\text { Aktiva Lancar }} \times 100 \%
$$

Tabel 3. Perhitungan Rasio Kas atas Aktiva Lancar

\begin{tabular}{|c|c|c|c|}
\hline Tahun : & Kas & Aktiva Lancar & \% \\
\hline 2015 & Rp.2.652.218.775 & Rp.24.337.188.602 & $10,90 \%$ \\
\hline 2016 & Rp.2.454.146.778 & Rp.34.348.947.509 & $7,14 \%$ \\
\hline 2017 & Rp.1.729.119.927 & Rp.23.863.314.187 & $7,25 \%$ \\
\hline
\end{tabular}

Sumber: Laporan Keuangan Koperasi Karyawan PT. Pusri Palembang Data yang Telah Diolah.

d. Rasio Kas atas Utang Lancar

Untuk mengukur likuiditas

Koperasi Karyawan PT. Pusri Palembang di gunakan rasio kas atas utang lancar. Rasio yang membandingkan antara kas yang bisa

Rasio kas atas utang lancar $=\frac{\text { Kas }}{\text { Utang Lancar }} \times 100 \%$

Tabel 4. Perhitungan Rasio Kas Atas Utang Lancar

\begin{tabular}{|c|c|c|c|}
\hline Tahun : & Kas & Utang Lancar & \% \\
\hline 2015 & Rp.2.652.218.775 & Rp.20.468.206.354 & $12,95 \%$ \\
\hline 2016 & Rp.2.454.146.778 & Rp.21.924.336.652 & $11,19 \%$ \\
\hline 2017 & Rp.1.729.119.927 & Rp.15.393.222.122 & $11,23 \%$ \\
\hline
\end{tabular}

Sumber: Laporan Keuangan Koperasi Karyawan PT. Pusri Palembang Data yang Telah Diolah.

e. Rasio Aktiva lancar dan Total

\section{Aktiva}

Untuk mengukur likuiditas

Koperasi Karyawan PT. Pusri Palembang di gunakan rasio aktiva lancar dan total aktiva. Rasio aktiva lancar dan total aktiva dihitung segera menjadi uang kas dengan utang lancar. Adapun rumus dan hasil perhitungan rasio kas atas utang lancarpada Koperasi Karyawan PT. Pusri Palembang sebagai berikut : 
Tabel 5. Perhitungan Rasio Aktiva Lancar dan Total Aktiva

\begin{tabular}{|c|c|c|c|}
\hline Tahun : & Aktiva Lancar & Total Aktiva & \% \\
\hline 2015 & Rp.24.337.188.602 & Rp.36.821.452.378 & $66,09 \%$ \\
\hline 2016 & Rp.34.348.947.509 & Rp.47.697.208.124 & $72,01 \%$ \\
\hline 2017 & Rp.23.863.314.187 & Rp.34.882.768.883 & $68,41 \%$ \\
\hline
\end{tabular}

Sumber: Laporan Keuangan Koperasi Karyawan PT. Pusri Palembang Data yang Telah Diolah.

f. Rasio Aktiva Lancar dan Total dengan cara aktiva lancar dibagi Utang dengan total utang dikali dengan

Untuk mengukur likuiditas $100 \%$. Adapun rumus dan hasil Koperasi Karyawan PT. Pusri perhitungan rasio aktiva lancar dan Palembang digunakan rasio aktiva total utangpada Koperasi Karyawan lancar dan total utang. Rasio aktiva PT. Pusri Palembang sebagai berikut: lancar dan total utang dihitung

Rasio aktiva lancar dan total utang $=\frac{\text { Aktiva Lancar }}{\text { Total Utang Jangka Pendek }} \times 100 \%$

Tabel 6. Perhitungan Rasio Aktiva Lancar dan Total Utang

\begin{tabular}{|c|c|c|c|}
\hline Tahun : & Aktiva Lancar & Total Aktiva & $\%$ \\
\hline 2015 & Rp.24.337.188.602 & Rp.36.821.452.378 & $66,09 \%$ \\
\hline 2016 & Rp.34.348.947.509 & Rp.47.697.208.124 & $72,01 \%$ \\
\hline 2017 & Rp.23.863.314.187 & Rp.34.882.768.883 & $68,41 \%$ \\
\hline
\end{tabular}

Sumber: Laporan Keuangan Koperasi Karyawan PT. Pusri Palembang Data yang Telah Diolah.

\subsection{Rasio Profitabilitas}

\section{a. Net Profit Margin}

Untuk mengukur profitabilitas Koperasi Karyawan PT. Pusri Palembang di gunakan net profit margin. Net Profit Margin dihitung dengan cara pendapatan bersih dibagipenjualan dikali dengan $100 \%$. Adapun rumus dan hasil perhitungan Net Profit Marginpada Koperasi Karyawan PT. Pusri Palembang sebagai berikut :

NPM $=\frac{\text { Pendapatan Bersih }}{\text { Penjualan }} \chi 100 \%$

\section{Tabel 7. PerhitunganNet Profit Margin}

\begin{tabular}{|c|c|c|c|}
\hline Tahun: & Pendapatan Bersih & Penjualan & $\%$ \\
\hline 2015 & Rp. 884.620 .577 & Rp. 21.767 .087 .342 & $40,64 \%$ \\
\hline 2016 & Rp. 1.006 .840 .750 & Rp. 24.789 .848 .999 & $40,61 \%$ \\
\hline 2017 & Rp. 1.048 .600 .255 & Rp. 26.316.230.113 & $39,84 \%$ \\
\hline
\end{tabular}

Sumber: Laporan Keuangan Koperasi Karyawan PT. Pusri Palembang Data yang Telah Diolah. 
b. Gross Profit Margin

Untuk mengukur profitabilitas Koperasi Karyawan PT. Pusri Palembang digunakan gross profit margin. Rasio ini mengukur tingkat laba kotor dibandingkan dengan volume pendapatan yang menunjukkan semakin besar hasil rasio semakin baik keadaan operasional perusahaan, karena menunjukkan harga pokok penjualan relatif rendah dibandingkan penjualan. Adapun rumus dan hasil perhitungan Gross Profit Marginpada Koperasi Karyawan PT. Pusri Palembang sebagai berikut :

$$
\mathrm{GPM}=\frac{\text { Laba } \text { Kotor }}{\text { Penjualan }} \times 100 \%
$$

Tabel 8. Perhitungan Gross Profit Margin

\begin{tabular}{|c|c|c|c|}
\hline Tahun : & Laba Kotor & Penjualan & $\%$ \\
\hline 2015 & Rp. 5.279 .244 .047 & Rp. 21.767 .087 .342 & $24,25 \%$ \\
\hline 2016 & Rp. 4.827 .893 .502 & Rp. 24.789 .848 .999 & $19,47 \%$ \\
\hline 2017 & Rp. 4.738.899.302 & Rp. 26.316.230.113 & $18,01 \%$ \\
\hline
\end{tabular}

Sumber: Laporan Keuangan Koperasi Karyawan PT. Pusri Palembang Data yang Telah Diolah.

\section{c. Asset Turn Over}

Untuk mengukur profitabilitas Koperasi Karyawan PT. Pusri Palembang di gunakan asset turn over. Asset Turn Over dihitung dengan cara Penjualan Bersih dibagi Total Aktiva dikali dengan $100 \%$. Adapun rumus dan hasil perhitungan
Asset Turn Over pada Koperasi Karyawan PT. Pusri Palembang sebagai berikut :

$$
\mathrm{ATO}=
$$

$\frac{\text { Penjualan Bersih }}{\text { Total Aktiva }} x \ldots . .$. kali

Tabel 9. Perhitungan Asset Turn Over

\begin{tabular}{|c|c|c|c|}
\hline Tahun: & Penjualan Bersih & Total Aktiva & kali \\
\hline 2015 & Rp. 5.279.244.047 & Rp. 36.821.452.378 & 0,14 kali \\
\hline 2016 & Rp. 4.827.839.502 & Rp. 47.697.208.124 & 0,10 kali \\
\hline 2017 & Rp. 4.738.899.302 & Rp. 34.882.768.883 & 0,13 kali \\
\hline
\end{tabular}

Sumber: Laporan Keuangan Koperasi Karyawan PT. Pusri Palembang Data yang Telah Diolah.

\section{d. Return on Asset}

Untuk mengukur Profitabilitas Koperasi Karyawan PT. Pusri Palembang di gunakan return on total aset. Return on Total Aset dihitung dengan cara asset lancar dibagi hutang lancar dikali dengan 100\%. Adapun rumus dan hasil perhitungan Return on Total Aset pada Koperasi 
Karyawan PT. Pusri Palembang

sebagai berikut :

$\mathrm{ROA}=\frac{\text { Laba Bersih }}{\text { Rata-rata } \text { Total Asset }} \times 100 \%$

Tabel 10. Perhitungan Return on Asset

\begin{tabular}{|c|c|c|c|}
\hline Tahun: & Laba Bersih & Total Aset & $\%$ \\
\hline 2015 & Rp. 884.620 .577 & $\begin{array}{c}\text { Rp. } \\
36.821 .452 .378\end{array}$ & $24,02 \%$ \\
& & Rp. 47.697 .208 .124 & $21,11 \%$ \\
\hline 2016 & Rp. 1.006 .840 .750 & Rp. 32.882.768.883 & $31,89 \%$ \\
\hline 2017 & Rp. 1.048 .600 .255 & Ken
\end{tabular}

Sumber: Laporan Keuangan Koperasi Karyawan PT. Pusri Palembang Data yang Telah Diolah.

e. Return On Equity

Ratio/Rentabilitas Modal Sendiri

Untuk mengukur Profitabilitas Koperasi Karyawan PT. Pusri Palembang di gunakan return on equity ratio. Return on equity ratio di hitung dengan cara sisa hasil usaha dibagi Modal usaha dikali dengan
100\%. Adapun rumus dan hasil perhitungan Return On Equity Ratio pada Koperasi Karyawan PT. Pusri Palembang sebagai berikut :

$$
\mathrm{ROE}=\frac{\text { SHU }}{\text { Modal Usaha }} \times 100 \%
$$

Tabel 11. Perhitungan Return On Equity Ratio

\begin{tabular}{|c|c|c|c|}
\hline Tahun & SHU & Modal Usaha & $\%$ \\
\hline 2015 & Rp. 74.310.683 & Rp. 10.114.265.917 & $73,47 \%$ \\
\hline 2016 & Rp. 71.715.290 & Rp. 9.989.265.226 & $71,79 \%$ \\
\hline 2017 & Rp. 58.730.729 & Rp. 9.111.243.347 & $64,46 \%$ \\
\hline
\end{tabular}

Sumber: Laporan Keuangan Koperasi Karyawan PT. Pusri Palembang Data yang Telah Diolah.

\section{Pembahasan}

1. Rasio Likuiditas

\subsection{Current Ratio}

Pada tahun 2015 current ratio Koperasi Karyawan PT. Pusri Palembang sebesar Rp. 118,90\%, hal ini berarti bahwa setiap $\mathrm{Rp} 1,00$ utang lancar akan dijamin dengan Rp 1,189 aktiva lancar. Pada tahun 2016 current ratio koperasi mengalami kenaikan sebesar $37,77 \%$ menjadi
156,67\% berarti setiap Rp 1,00 utang lancar dijamin dengan $\mathrm{Rp} 1,567$ aktiva lancar, kenaikan ini disebabkan oleh kenaikan aktiva lancar sebesar Rp. 34.348.947.509 dan juga meningkatnya utang lancar sebesar Rp. 21.924.336.652. pada tahun 2017 current ratio koperasi mengalami penurunan sebesar $1.65 \%$ menjadi $155,02 \%$, hal ini berarti bahwa setiap Rp 1,00 utang lancar 
dijamin oleh Rp 1,550 aktiva lancar, penurunan ini disebabkan penurunan aktiva lancar sebesar Rp. 23.863.314.187 dan diikuti penurunan utang lancar sebesar Rp. 15.393.222.222.

Berdasarkan Standar Peraturan Menteri No: 06/Per/M.KUKM/V/2006 agar tergolong kategori sehat persentase current ratio yang harus dicapai ialah sebesar $<175 \%$. Dan jika dilihat dari persentase keseluruhan Koperasi Karyawan PT. Pusri Palembang mampu mencapai $155,02 \%$ dan termasuk dalam kategori cukup sehat.

\subsection{Quick Ratio}

Pada tahun 2015 quick ratio koperasi karyawan PT. Pusri Palembang sebesar Rp. 113,02\%, hal ini berarti bahwa setiap $\mathrm{Rp} 1,00$ utang lancar senilai Rp 1,00 akan dijamin oleh quick assets senilai $\mathrm{Rp}$ 1,130. Pada tahun 2016 quick ratio koperasi mengalami kenaikan sebesar $38,4 \%$ menjadi $151,42 \%$ yang berarti setiap utang lancar senilai $\mathrm{Rp}$ 1,00 akan dijamin oleh quick assets senilai Rp 1,514 hal ini terjadi karena adanya kenaikan utang lancar sebesar Rp. 21.924.336.652, sementara quick assets mengalami kenaikan senilai Rp. 34.348.947.509. Pada tahun 2017 quick ratio koperasi mengalami penurunan sebesar $2,45 \%$ menjadi $151,42 \%$, setiap utang lancar senilai Rp 1,00 akan dijamin quick assets senilai $\mathrm{Rp}$ 1,514 penurunan ini disebabkan oleh penurunan aktiva lancar sebesar Rp. 23.863.314.187 dan diikuti dengan penurunan utang lancar sebesar Rp. 15.393.222.122.

Sedangkan menurut Standar Peraturan Menteri No: 06/Per/M.KUKM/V/2006 agar tergolong kategori sehat persentase quick ratio yang harus dicapai ialah sebesar $<175 \%$. Dan jika dilihat dari persentase keseluruhan Koperasi Karyawan PT. Pusri Palembang mampu mencapai $151,42 \%$ dan termasuk dalam kategori cukup sehat.

\subsection{Rasio Kas Atas Aktiva Lancar}

Pada tahun 2015 rasio kas atas aktiva lancar Koperasi Karyawan PT. Pusri Palembang sebesar 10,90\% berarti pada tahun 2015 setiap Rp 1,00 aktiva lancar akan dijamin dengan Rp 0,109 kas koperasi. Pada tahun 2016 kas koperasi mengalami penurunan sebesar $3,76 \%$ menjadi $7,14 \%$, setiap Rp 1,00 aktiva lancar akan dijamin dengan Rp 7,14 kas koperasi, penurunan ini disebabkan oleh total kas sebesar Rp.2.454.146.778 dan meningkatnya utang lancar sebesar Rp.34.348.947.509. pada tahun 2017 cash ratio koperasi mengalami peningkatan sebesar $0,11 \%$ menjadi $7,25 \%$, hal ini berarti bahwa setiap Rp 1,00 aktiva lancar akan dijamin oleh Rp 0,725 kas koperasi, penurunan ini disebabkan menurunya total kas sebesar Rp. 1.729.119.927 
dan diikuti penurunan aktiva lancar sebesar Rp. 23.863.314.187.

Sedangkan

berdasarkan

Peraturan Menteri No:

06/Per/M.KUKM/V/2006 agar

tergolong kategori sehat persentase

Rasio Kas Atas Aktiva Lancaryang harus dicapai ialah sebesar $<175 \%$. Dan jika dilihat dari persentase keseluruhan Koperasi Karyawan PT. Pusri Palembang hanya mampu mencapai $8,43 \%$ dan termasuk dalam kategori tidak sehat. Hal ini disebabkan karena flow cash atau arus kas Koperasi yang tidak berjalan dengan lancar setiap tahunnya mengalami penurunan. Dan aktiva lancar yang dimiliki dalam selalu berfluktuatif.।

\subsection{Rasio kas Atas Utang Lancar}

Pada tahun 2015 cash ratio koperasi karyawan PT. Pusri Palembang sebesar $12,95 \%$, berarti pada tahun 2011 setiap $\mathrm{Rp} 1,00$ utang lancar akan dijamin dengan $\mathrm{Rp}$ 0,129 kas koperasi. Pada tahun 2016 cash ratio koperasi mengalami penurunan $1,76 \%$ menjadi $11,19 \%$, setiap Rp 1,00 utang lancar akan dijamin dengan $\mathrm{Rp} \quad 0,119$ kas koperasi, penurunan ini disebabkan oleh penurunan kas sebesar Rp 2.454.146.778 dan meningkatnya utang lancar sebesar Rp. 21.924.336.652. pada tahun 2017 cash ratio koperasi mengalami kenaikan sebesar $0.04 \%$ menjadi $11,23 \%$, hal ini berarti bahwa setiap Rp 1,00 utang lancar akan dijamin oleh Rp 0,112 kas koperasi, penurunan ini disebabkan menurunnya total kas sebesar Rp.1.729119.927 dan diikuti total utang lancar sebesar Rp. 15.393.222.122.

Sedangkan berdasarkan Peraturan Menteri No: 06/Per/M.KUKM/V/2006 agar tergolong kategori sehat persentase Rasio Kas Atas Utang Lancaryang harus dicapai ialah sebesar $<175 \%$. Dan jika dilihat dari persentase keseluruhan Koperasi Karyawan PT. Pusri Palembang hanya mampu mencapai $11,80 \%$ masih termasuk ke dalam kategori tidak sehat. Hal ini disebabkan karena flow cash atau arus kas Koperasi tidak berjalan dengan lancar setiap tahunnya. dan jumlah kas koperasi tidak mampu menutupi utang lancar koperasi. Namun hal tersebut tidak menggangu aktivitas operasional koperasi, karena pihak manajemen koperasi sudah mempunyai strategi untuk menutupi kekurangan tersebut. Salah satunya dengan sumber modal utama koperasi yang besar.

\subsection{Rasio Aktiva Lancar dan Total Aktiva \\ Pada tahun 2015 rasio aktiva} lancar dan total aktiva Koperasi Karyawan PT. Pusri Palembang senilai 66,09\%, hal ini berarti bahwa setiap $\mathrm{Rp} 1,00$ total aktiva lancar akan dijamin dengan Rp.0,660 total aktiva. Pada tahun 2016 rasio aktiva lancar dan total aktiva koperasi 
mengalami kenaikan sebesar 5,92\% menjadi $72,01 \%$ yang berarti bahwa setiap Rp 1,00 total aktiva lancar akan dijamin Rp 0,720 total aktiva, hal ini terjadi karena adanya kenaikan total aktiva sebesar Rp.34.348.947.509 dan diikuti kenaikan total aktiva sebesar Rp. 47.697.208.124. pada tahun 2017 rasio aktiva lancar dan total aktiva koperasi mengalami penurunan sebesar $3,6 \%$ menjadi $68,41 \%$, hal ini berarti bahwa setiap Rp 1,00 total aktiva lancar akan dijamin dengan Rp.0,684 total aktiva, penurunan ini disebabkan oleh menurunnya total aktiva lancar sebesar Rp.23.863.314.187 dan diikuti penurunan total aktiva sebesar Rp.34.882.768.883.

Sedangkan berdasarkan

Peraturan Menteri No:

06/Per/M.KUKM/V/2006 agar tergolong kategori sehat persentase Rasio Aktiva Lancar dan Total Aktivayang harus dicapai ialah sebesar $<175 \%$. Dan jika dilihat dari persentase keseluruhan Koperasi Karyawan PT. Pusri Palembang hanya mampu mencapai 11,80\% masih termasuk ke dalam kategori tidak sehat. Hal ini disebabkan karena flow cash Koperasi tidak berjalan dengan lancar, dan piutang usaha yang meningkat. Salah satu contoh dari bidang usaha ketenagakerjaan non pabrik yang dikelola koperasi mengalami permasalahan dalam pelunasan utang pada koperasi.
1.6 Rasio Aktiva Lancar dan Total Utang

Pada tahun 2015 rasio aktiva lancar dan total utang Koperasi Karyawan PT. Pusri Palembang sebesar 39,00\%, hal ini berarti bahwa setiap Rp 1,00 total utang akan dijamin dengan Rp 0,390 aktiva lancar. Pada tahun 2016 rasio aktiva lancar dan total utang koperasi mengalami penurunan sebesar $17,24 \%$ mejadi $21,76 \%$ berarti setiap Rp 1,00 total utang dijamin Rp 0,217 aktiva lancar, penurunan ini disebabkan oleh kenaikan aktiva lancar sebesar Rp.34.348.974.509 dan meningkatnya total utang sebesar Rp.15.783.606.245. pada tahun 2017 rasio aktiva lancar dan total utang koperasi mengalami peningkatan sedikit dari tahun sebelumnya sebesar $1,21 \%$ menjadi $22,97 \%$, hal ini berarti bahwa setiap Rp. 1,00 total utang dijamin oleh Rp 0,229 aktiva lancar sebesar Rp. 23.863.314.187 dan diikuti penurunan total utang sebesar $\mathrm{Rp}$. 10.387.303.413.

Sedangkan berdasarkan Peraturan Menteri No: 06/Per/M.KUKM/V/2006 agar tergolong kategori sehat persentase Rasio Aktiva Lancar dan Total Aktivayang harus dicapai ialah sebesar < $175 \%$. Dan jika dilihat dari persentase keseluruhan Koperasi Karyawan PT. Pusri Palembang hanya mampu mencapai $11,79 \%$ masih termasuk ke dalam kategori tidak sehat. Hal ini disebabkan 
karena flow cash Koperasi tidak berjalan dengan lancar, dan piutang usaha yang meningkat. Akan tetapi pihak koperasi selalu mempunyai solusi untuk menyelesaikan masalah tersebut dengan cara mempercepat proses penagihan dan mengkonfirmasi segera ke pihak user sebelum jatuh tempo pembayaran.

\section{Rasio Profitabilitas}

\subsection{Net Profit Margin}

Pada tahun 2015 Net Profit Margin Koperasi Karyawan PT. Pusri Palembang senilai 40,64\%, hal ini berarti bahwa setiap $\mathrm{Rp} 1,00$ penjualan menghasilkan laba bersih sebesar Rp. 0,406 . Pada tahun 2016 net profit margin koperasi mengalami penurunan sebesar $0,03 \%$ menjadi $40,61 \%$ hal ini terjadi karena pendapatan bersih mengalami kenaikan Rp. 1006.840.750 dan diikuti meningkatnya penjualan sebesar Rp. 24.789.848.999. pada tahun 2017 net profit margin koperasi mengalami penurunan sebesar $0,77 \%$ menjadi $39,84 \%$, hal ini berarti bahwa setiap Rp 1,00 penjualan menghasilkan sebesar Rp. 0,398 . Penurunan ini disebabkan karena adanya kenaikan pendapatan bersih sebesar Rp. 1.048.600.255 dan diikuti dengan kenaikan penjualan sebesar Rp. 26.316.230.113.

Berdasarkan Standar Peraturan Menteri No: 06/Per/M.KUKM/V/2006 agar tergolong kategori sehat persentase net profit marginyang harus dicapai ialah sebesar $>15 \%$. Dan jika dilihat dari persentase keseluruhan Koperasi Karyawan PT. Pusri Palembang mampu mencapai 40,36\% dan termasuk dalam kategori sangat sehat. Hal ini terlihat dari pendapatan dan penjualan yang meningkat disetiap tahunnya.

\subsection{Gross Profit Margin}

Pada tahun 2015 gross profit Margin Koperasi Karyawan PT. Pusri Palembang senilai 24,25\%, hal ini berarti bahwa setiap $\mathrm{Rp} 1,00$ poendapatan yang dihasilkan akan memperoleh laba kotor sebesar Rp 0,242. Pada tahun 2016 gross profit margin koperasi mengalami penurunan sebesar $4,78 \%$ menjadi $19,47 \%$ yang bearti bahwa setiap Rp 1,00 pendapatan yang dihasilkan akan memperoleh laba kotor sebesar Rp 0,194, hal ini terjadi karena laba kotor koperasi mengalami penurunan sebesar Rp. 4.827.893.502 dan diikuti meningkatnya penjualan sebesar Rp. 24.789.848.999. pada tahun 2017 gross profit margin koperasi mengalami penurunan kembali sebesar $1,46 \%$ menjadi $18,01 \%$, hal ini berarti bahwa setiap Rp 1,00 pendapatan yang dihasilkan akan memperoleh laba kotor sebesar Rp 0,180, penurunan ini disebabkan adanya penurunan laba kotor sebesar Rp. 4.738.899.302 dan diikuti kenaikan penjualan sebesar Rp. 26.316.230.113.

Berdasarkan Standar Peraturan Menteri

No: 
06/Per/M.KUKM/V/2006 agar tergolong kategori sehat persentase gross profit margin yang harus dicapai ialah sebesar $>15 \%$. Dan jika dilihat dari persentase keseluruhan Koperasi Karyawan PT. Pusri Palembang mampu mencapai $20,57 \%$ dan termasuk dalam kategori sangat sehat. Hal ini terlihat dari laba kotor yang diperoleh setiap tahun menurun dan penjualan meningkat setiap tahunnya.

\subsection{Asset Turn Over}

Pada tahun 2015 asset turn over Koperasi Karyawan PT. Pusri Palembang sebesar 1,4 kali perputaran, pada tahun 2016 asset turn over mengalami penurunan sebesar 1,1 kali perputaran, sedangkan pada tahun 2017 sebesar 1,3 kali. Hal ini berarti bahwa nilai nominal aktiva yang didapat tidak berputar begitu cepat sehingga laba yang didapat kurang begitu maksimal, volume penjualan pun juga berpengaruh semakin kecil nominal penjualan yang didapat maka akan mempengaruhi nilai asset turn over yang dimiliki.

Berdasarkan Standar Peraturan Menteri No: 06/Per/M.KUKM/V/2006 agar tergolong kategori sehat persentase asset trun over yang harus dicapai ialah sebesar > 3,5 kali perputaran. Dan jika dilihat dari persentase keseluruhan Koperasi Karyawan PT. Pusri Palembang mampu mencapai
0,13 kali perputaran dan termasuk dalam kategori tidak sehat.

\subsection{Return On Asset}

Berdasarkan Standar Peraturan Menteri No: 06/Per/M.KUKM/V/2006 agar tergolong kategori sehat persentase return on assetyang harus dicapai ialah sebesar $>10 \%$. Dan jika dilihat dari persentase keseluruhan Koperasi Karyawan PT. Pusri Palembang mampu mencapai $25,67 \%$ dan termasuk dalam kategori sangat sehat. Hal ini terlihat dari laba bersih yang dihasilkan setiap tahun meningkat dan diikuti peningkatan total asset yang meningkat secara flutuatif.

\subsection{Return On Equity}

Pada tahun 2015 return on equity Koperasi Karyawan PT. Pusri Palembang senilai $73,47 \%$, hal ini berarti bahwa setiap Rp 1,00 modal sendiri akan memperoleh laba bersih sebesar Rp. 0,734. Pada tahun 2016 return on equity koperasi mengalami penurunan sebesar $1,68 \%$ menjadi $71,79 \%$ yang berarti bahwa setiap Rp 1,00 modal sendiri akan memperoleh laba bersih sebesar Rp 0,717, hal ini terjadi karena laba bersih mengalami penurunan sebesar Rp. 71.715.290 dan diikuti modal sendiri mengalami penurunan sebesar Rp. 9.989.265.226. pada tahun 2017 return om equity koperasi mengalami penurunan kembali sebesar 7,33\% menjadi $64,46 \%$, hal ini berarti 
bahwa setiap Rp 1,00 modal sendiri akan memperoleh laa bersih sebesar Rp 0,644, penurunan ini disebabkan karena adanya penurunan laba bersih sebesar Rp. 58.730 .729 dan diikuti penurunan modal sendiri sebesar $\mathrm{Rp}$. 9.111.243.347.

Berdasarkan Standar Peraturan Menteri No: 06/Per/M.KUKM/V/2006 agar tergolong kategori sehat persentase return on equity / Rentabilitas Modal sendiriyang harus dicapai ialah sebesar $>21 \%$. Dan jika dilihat dari persentase keseluruhan Koperasi Karyawan PT. Pusri Palembang mampu mencapai $69,90 \%$ dan termasuk dalam kategori sangat sehat.

\section{SIMPULAN DAN SARAN}

\section{Simpulan}

Berdasarkan pembahasan yang telah dijelaskan peneliti pada bab sebelumnya, bahwa pada kurun waktu tahun 2015 sampai tahun 2017 rasio likuiditas dan rasio profitabilitas koperasi karyawan PT. Pusri Palembang sebagai berikut:

1. Di lihat dari rasio likuiditas:

a. Current ratio dan Quick ratio pada tahun 2015 sampai tahun 2017 menunjukkan kinerja keuangan cukup sehat karena memenuhi kriteria current ratio yaitu $125 \%$ - <150\%.

b. Sedangkan Rasio kas atas aktiva lancar, Rasio kas atas utang lancar, Rasio aktiva lancar dan total aktiva, Rasio aktiva lancar dan total utang pada tahun 2015 sampai tahun 2017 menunjukkan kinerja keuangan kurang sehat karena masih dibawah standar yaitu $<100 \%$. Hal ini disebabkan karena siklus penagihan utang yang kurang lancar pada salah satu bidang usaha yaitu penyedia jasa borongan tenaga kerja non organik akan tetapi hal tersebut tidak mempengaruhi kelancaran aktivitas operasional koperasi karena bisa diminimalisir dengan sumber modal dan laba Koperasi Karyawan PT. Pusri Palembang yang cukup besar.

2. Dilihat dari Rasio Profitabilitas:

Net Profit Margin, Gross Profit Margin, Asset turn over, Return on Asset, Asset turn over, pada tahun 2015 sampai tahun 2017 menunjukkan kinerja keuangan sangat sehat karena memenuhi kriteria Standar Peraturan Menteri Negara koperasi dan Usaha 
Kecil Menengah Republik Indonesia tahun 2006.

Berdasarkan perhitungan rasio likuiditas dan profitabilitas tersebut bahwa Koperasi Karyawan PT. Pusri Palembang dalam kategori koperasi sehat menurut Peraturan Menteri Negara koperasi dan Usaha Kecil Menengah Republik Indonesia Nomor: 06/Per/M.KUKM/V/2006.

\section{Saran}

Peneliti memberikan saran dan berharap saran ini dapat memberikan manfaat bagi semuanya, diantaranya sebagai berikut:

1. Bagi pihak Koperasi Karyawan PT. Pusri Palembang harus memperhatikan dalam pengendalian biaya-biaya dan tingkat penjualan secara efisien dan efektif, sehingga dapat meningkatkan kemampuan dalam menghasilkan laba bersih yang berhubungan dengan tingkat penjualan dan biayabiaya yang dikeluarkan dalam kegaiatan operasionalnya pada setiap tahunnya yang menentukan hasil kinerjanya.

2. Bagi Anggota Koperasi Karyawan PT. Pusri Palembang lebih meningkatkan tabungan pada koperasi dan mengembalikan angsuran pinjaman di koperasi secara rutin.

3. Bagi Peneliti selanjutnya diharapkan dapat memperluas objek penelitian dan menambah variabel menggunakan rasio keuangan lainnya seperti rasio aktivitas dan rasio solvabilitas yang dapat mendukung hasil penelitian selain menggunakan rasio likuiditas dan profitabilitas.

\section{DAFTAR PUSTAKA}

Aprilia, Anita. 2014. Analisis Rasio Keuangan Untuk Mengukur Kinerja Keuangan Pada Koperasi Dhaya Harta Jombang. Jurnal ilmu dan Riset Akuntansi Vol. 3 No.4.

Arikunto, Suharsimi. 2014. Prosedur Penelitian. Jakarta: Rineka Cipta.

Baswir, Revrisond. 2013. Koperasi Indonesia. Yogyakarta: BPFE.

Bintoro, Daryanto. 2017 Manajemen Penilaian Kinerja Karyawan. Yogyakarta: Gava Media.

Deniyanto, Risci Dwi. 2015. Analisis kinerja keuangan pada koperasi simpan pinjam (KSP) Bina Usaha Utama Tahun 2012-2014. Universitas Dian Nuswantoro, Semarang.

Fadli, Uus Md, dkk. 2012. "Analisis Kinerja Keuangan Pada Koperasi Karyawan Kantor Kementerian Agama Karawang." Jurnal Manajemen Vol.09 No.4.

Harahap, Sofyan Syaftri. 2010. Analisis Kritis atas Laporan 
Keuangan. Jakarta: PT RajaGrafindo Persada.

Irham Fahmi. 2011. Manajemen Kinerja Teori dan Aplikasi. Bandung: Alfabeta.

Jumingan. 2009. Analisis Laporan Keuangan. Jakarta: PT. Bumi Aksara.

Kasmir. 2017. Analisis Laporan Keuangan. Jakarta: PT Raja Grafindo Persada.

Munawir. 2010. Analisa Laporan Keuangan. Yogyakarta: Liberty.

Nazir, Moh. 2014. Metode Penelitian. Bogor: Ghalia Indonesia.

Peraturan Menteri Negara Koperasi dan Usaha Kecil Menengah Republik Indonesia Nomor: 06/Per/M.KUKM/V/2006.

Sari, I Gusti Ayu Normaya, Nurul Mahmuda. Analisis Kinerja Keuangan Koperasi Pegawai Republik Indonesia (KPRI) Handayani Kabupaten Pemalang Periode 2011-2015. Jurnal MONEX Vol. 6 No. 2 juni 2017 Prosiding ISSN: 2089-5321.

Sugiono, Arief dan Edi Untung. 2016. Panduan Praktis Dasar Analisis Laporan Keuangan. Jakarta: PT. Grasindo.

Sugiyono. 2016. Metode Penelitian Pendidikan. Bandung: Alfabeta.

Sujarweni, V. Wiratna. 2017. Analisis Laporan Keuangan Teori, Aplikasi dan Hasil Penelitian. Yogyakarta: Pustaka Baru Press.
Tim Penyusun. 2017. Pedoman Penulisan Skripsi. Palembang: FKIP.Univ. PGRI Palembang. Undang-Undang Republik Indonesia No. 17 Tahun 2012 Tentang 